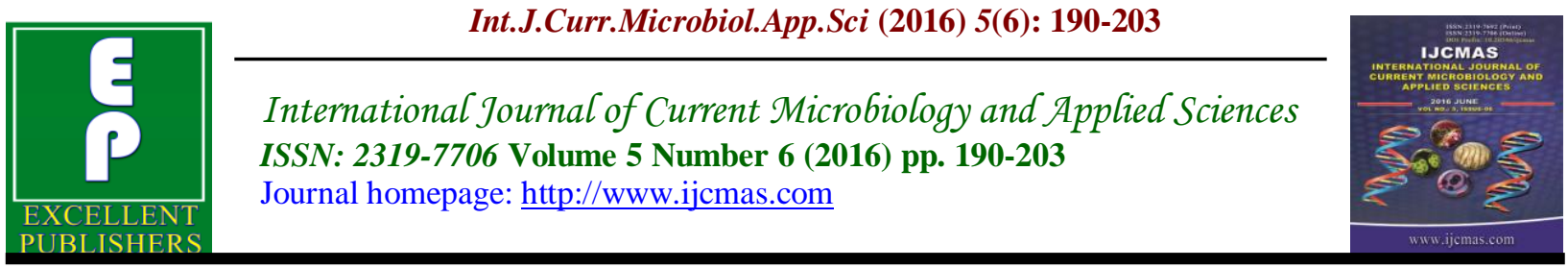

Original Research Article

http://dx.doi.org/10.20546/ijcmas.2016.506.023

\title{
A New Record of Endemic and Critically Endangered Mycorrhizal Plant: Ceropegia rollae Hemadri from India
}

\author{
Vishal R. Kamble ${ }^{1 *}$, Ruchira R. Sutar ${ }^{2}$ and Dinesh G. Agre ${ }^{3}$ \\ Mycorrhizal Research Laboratory \& PG Department of Botany, Bhartiya Vidya Bhavan's \\ Bhavan's College Andheri (West), 400058, M.M. College of Arts, N.M. Institute of Science, \\ H.R.J. College of Commerce, MS, India \\ *Corresponding author
}

\section{A B S T R A C T}

\section{Keywords}

Acaulospora undulata, Arbuscular mycorrhizal fungi (AMF), Ceropegia rollae Hemadri, Rare endangered and threatened (RET) plants.

\section{Article Info}

\section{Accepted:}

12 May 2016

Available Online:

10 June 2016
Ceropegia rollae Hemadri (Apocynaceae) an endemic and critically endangered plant was first time recorded from a mountain pass in the Western Ghats ranges of Maharashtra known as Naneghat [19³0'64', N \& $73^{\circ} 67^{\prime} 99^{\prime}$ ' E] treated as a new locality other than previously reported by plant taxonomists. Present paper deals with assessment of Arbuscular mycorrhizal fungi (AMF) associated with plant. Overall colonization intensity was $73.03 \pm 1.03 \%$ in cleared and stained roots. Detailed microscopic investigations of $C$. rollae roots confirmed mycorrhizal status of plant. Total nine Arbuscular mycorrhizal fungi (AMF) viz., Acaulospora bireticulata, A. laevis, A. undulata, Ambispora leptoticha, Dentiscutata reticulata, Entrophospora baltica, Gigaspora gigantea, Glomus austral and Scutellospora dipurpusescrns were extracted from rhizosphere soil. Based on spore density and relative abundance Acaulospora undulata was diagnosed as dominant AMF species of $C$. rollae.

\section{Introduction}

In the recent past, Northern part of Western Ghats of India has been subjected to rapid urbanization due to its proximity to the Mumbai which is an international economic hub. In general severe anthropogenic pressures on the forest area have caused major threats to existing species. Many sites in this region are prone to habitat destructions of rare plant species due to recreation, tourism and adventure activities.
A mountain pass in the Western Ghats ranges known as Naneghat [19³0'64', N and 73०67'99', E] (Figure 1) is one of the threatened place where we have recently reported Ceropegia rollae Hemadri (Apocynaceae, Ceropegieae, Stapeliinae) an endemic and critically endangered plant species (Figure 2). In present paper this plant species is assessed for its mycorrhizal status. 
In India 58 species, 2 subspecies and 4 varieties of genus Ceropegia L. are found (Malpure et al., 2006; Diwakar and Singh, 2011; Kambale et al., 2012) of these 35 species and one variety are endemic to Western Ghats of India (Singh, 2015) which is designated as world's biodiversity hotspots region. At present total 17 species and one variety are strictly endemic to Maharshtra state. As per the IUCN categories many species of the genus Ceropegia have now been added to the list of Indian endangered plants (BSI, 2002) which are placed under the categories of rare, endangered, vulnerable, extinct, and threatened plants (Nayar and Sastry, 1987; Goyal and Bhadauria, 2006; Gadgil, 2004), C. rollae is one of those, which is commonly known as Rolla's Ceropegia and Kharpudi locally. It is a tuberous, erect, broad leaved species with many flowered cymose inflorescence.

The intricate and ornamental nature of Ceropegia flowers has gain horticultural importance (CITES, 2007). Unfortunately starch enriched tubers are susceptible to fungal attack hence vegetative propagation and maintenance is difficult. The habitat destruction caused through anthropogenic activities and over exploitation of edible and medicinal tubers by local people, constrained small localized and dwindling populations of $C$. rollae. According to Singh (2015), current population of $C$. rollae consists of only sporadic and fragmented small patches of 12 to 15 individuals each and it could not be located from any other site except the earlier three viz, Harishchandragarh (Ahmednagar district), Dhak Khilla, Junnar- type locality and Durga Khila (Pune district). However in present study we have first time recorded this species from Naneghat a new locality other than previously reported by plant taxonomists.
Now days, many techniques for plant protection and conservation are being applied to multiply and maintain threatened plant species ex situ. However, to introduce rare plants to new sites under conservation program and to offset effects of habitat destruction, it needs detailed knowledge of habitat requirements, plant demography, and management (Holl and Hayes, 2006). Regrettably it is noticed that, the diversity and dynamics of macro and micro habitats associated with these plant species is not taken in to consideration in conservation programs. Day by day demise of endemic or endangered plants, populations is affecting the diversity and dynamics of macro and micro habitats. Many organisms and species may become extinct before their potential is realized (Kamble et al., 2012).

Soil microorganisms, especially Arbuscular Mycorrhizal Fungi (AMF), are considered to be crucial for proper plant performance (Smith and Read, 1997; Turnau and Haselwandter, 2002). Many researchers (Fisher and Jayachandran, 2002; Turnau and Haselwandter, 2002; Fuchs and Haselwandter, 2004) have considered usefulness of AMF in the development of effective methods for the maintenance and propagation of threatened plant species. However, 'the list of the International Union for Conservation of Nature and Natural Resources (IUCN Red List of Threatened Species) indicates that the mycorrhizal status of most of the threatened species has not been assessed. Rare plants often occur in specialized and also endangered habitats and might utilize specialized or unique AMF. The specificity of any endangered plant to its AMF population has not been investigated' (Bothe, et al., 2010). Today a big challenge in conservation biology is to prevent habitat loss of rare endangered and threatened (RET) plants. With habitat loss or demise of RET plants consequently could 
lead to extinction of many native AMF ecotypes without assessing their status or diversities in rhizosphere of such RET plants. Hence, it is urgently needed to understand naturally associated AMF species in rhizosphere of endemic or endangered plants. Such investigations could provide valuable inputs to technology being used in conservation. Present investigation makes in-depth analysis of observations on AMF colonization pattern and species associated with endemic and endangered plant $C$. rollae.

\section{Materials and Methods}

\section{Site Description}

During present investigation this species was observed for the first time at Naneghat which is a new location for distribution pattern of $C$. rollae. The study area is located in Pune district at elevation of 750 meters above sea level. It is situated about $55 \mathrm{~km}$ away from Kalyan, near the village Vaishakare. The plant grows in grasses and herbs on the steeping edges but at open area of hill top. C. rollae population at Naneghat hill site consisted of about 75 individuals which were exposed to significant anthropogenic disturbances with continuous human infringement such as recreation and picnic centre, rock climbing and mountaineering etc. (Figure 1) during the flowering and fruit setting period of plant in rainy season. Hence current population could be face further shrinkage of population. This is the most threatening season as the human interference only adds to other developmental pressures such as grazing the livestock and harvesting of edible tubers at the cost of uprooting the plants. Thus due to extensive anthropogenic activities at study area $C$. rollae has been intensely exposed to the threat of habitat destruction. The magnitude of the destruction may even amount to the complete loss of a given species habitat and hence needs immediate measures for its conservation. Extensive field visits were carried out during Aug - October 2015 for better understanding of plant species from taxonomical perspective. Plants identification and nomenclature is that of (Jagtap and Das-Das, 2001). Authentically identified plant specimens were dry preserved and deposited in departmental herbarium.

\section{Soil Sampling}

Sampling area consisted of sporadic and fragmented small patches of 5 to 10 individuals were selected haphazardly. Total five plants were sampled for soil collection. However, plant specimens were sampled in triplicates for root screening study purpose, so that these plants should not be damaged or destroyed further. The plants along with the rhizosphere soil samples and roots were collected in different collection bags and transported to laboratory and immediately refrigerated at $4^{\circ} \mathrm{C}$ subsequent to arrival and roots were processed immediately. All the five rhizosphere soil samples were homogenized prior to remove coarse roots segments, stones and adhered particles through sieving procedure. Subsamples of soil were air dried and used for estimation of physico-chemical properties.

\section{Physicochemical Parameters of Soil}

Soil texture and moisture was estimated gravimetrically (Jackson, 1967. Soil pH was analysed on 1:2.5, soil : water suspension (van Reeuwijk, 2002). Organic carbon was analyzed by WB rapid titration method (Walkley and Black, 1938) using $1 \mathrm{~N}$ potassium dichromate and back titrated with $0.5 \mathrm{~N}$ ferrous ammonium sulphate solution. Carbonate was estimated by Piper's rapid 
titration method (Piper, 1966) and available Olsen's phosphorus in soils was determined by extraction with $0.5 \mathrm{M}$ sodium bicarbonate for $30 \mathrm{~min}$ (Olsen et al., 1954).

\section{AMF Colonization in Roots}

To determine the colonization percentage, root samples processed were washed under running tap water, and cut in segmments $1 \mathrm{~cm}$ in length and stained for rapid mycorrhizal association following the method of Phillips and Hayman (1970). Assessment of root colonization was performed on each stained root piece microscopically Hundred stained root segments were assessed for colonization percentage using the intercept method (Brundrett, et al., 1996). A root piece was considered for counting as colonized by AMF when any mycorrhizal component such as hyphae, vesicles or arbuscles were observed. All three AMF components were interpreted for occurrence intensity viz., poor (1-25\%), moderate (25-50\%), good $(50-75 \%)$ and excellent (>75\%) which was denoted as ' $p, m, g$ and $e$ ' respectively. To interpret occurrence intensity $(O I)$ of fungal structures, mean colonization percentage $(M C p)$ for each fungal structure ( $V$ : vesicles, $A$ : arbuscules and $H$ : hyphae) was determined separately. Based on microscopic observations of randomly selected 100 root segments pattern of AMF colonization for $C$. rollae was determined. Any other special structures present in root piece were also recorded.

\section{AMF Spore Extraction}

From the $100 \mathrm{~g}$ of rhizosphere soil Spores were extracted by using sieving and decanting technique (Gerdemann and Nicolson, 1963) and total spore numbers of AMF in the soil sample were estimated following Gaur and Adholeya (1994). The spores microscopic observations were performed by mountings in a polyvinyl- lactoglycerol (PVLG) and PVLG solution mixed with Melzer's reagent 1:1 (v/v) ratio (Morton, 1988). All the spores were examined under stereomicroscope (Olympus $003421)$ at $10 \mathrm{X}, 40 \mathrm{X}$ and $100 \mathrm{X}$ magnifications. Photomicrographs were taken with the help of Canon IXUS 155 digital Camera.

\section{AMF Species Identification}

AMF spores and sporocarps up to species level were identified based on spore size, colour, wall layers and hyphal attachments using bibliographies by Schenck and Perez (1990) and also by matching descriptions of AMF species available at International Culture Collection of Vesicular and Arbuscular Endomycorrhizal Fungi [http://www.invam.wvu.edu/]. Voucher slide specimens were assigned accession codes 'BCA: $M_{R R S} \mathrm{n}$ ' [where, BCA:MH Bhavan's College Andheri: Mycological Herbarium; RRS initials of second Author and n-number assigned'] and preserved in Mycorrhizal Research Laboratory of Department.

The spore density (S) was expressed as number of spores per $100 \mathrm{~g}$ of soil. Relative abundance (RA) was defined as the percentage of spore numbers of a species divided by the total spores observed (Dandan and Zhiwei, 2007). The relative abundance (RA > 6\%) and spore density (S $\geq 40$ spores) was taken in to consideration to determine dominant AMF species. Statistical data processing for percentage colonization in roots, spore density and relative abundance of AMF species was performed for standard errors of means by using Microsoft excel 2007.

\section{Results and Discussion}

\section{Physicochemical parameters of soil}

In strategic plantation physicochemical properties of soil should be taken into 
consideration because soil requirement for any plant and associated microbes varies from species to species. It provides data with optimum requirement values in favour of plant species and associated of microhabitats sustaining under natural conditions. Similarly physicochemical properties of soil are important actors in conservation strategies for endemic and endangered plant species. Physicochemical properties of the rhizosphere soil of $C$. rollae are presented in Table 1. The soil had acidic $\mathrm{pH}$ 6.1; organic carbon $0.54 \%$, organic matter $0.93 \%$, carbonate content $12.09 \mathrm{mg} . \mathrm{kg}^{-1}$, Olsen's Phosphorus content $19.40 \mathrm{mg} \cdot \mathrm{kg}^{-1}$. In general, soil is slightly red, lateritic gravel in texture, acidic in reaction; low in organic matter, carbonate content and available phosphorus level.

\section{AMF Colonization in Roots of $C$. rollae}

The mycorrhizal colonization by each fungal structure in the roots of $C$. rollae is illustrated in Figure 3. The cleared and stained root segments of $C$. rollae showed $73.03 \pm 1.03 \%$ overall colonization i.e., overall colonization intensity is good (in the range of $50-75 \%$ ). We also determined the mean colonization percentage $(M C p)$ for each fungal structure ( $V$ : vesicles, $A$ : arbuscules and $H$ : hyphae) separately which was $96.80 \pm 1.4 ; 27.70 \pm 0.5$ and 94.60 $\pm 1.2 \%$ respectively for vesicles, arbuscules and hyphae (Table 2). Thus, we found $M C p>75 \%$ i.e. excellent occurrence intensity $(O I)$ for vesicular and hyphal colonization but slightly moderate (OI: 25$50 \%$ ) arbuscular colonization. In addition, we found variation in wall thickness in vesicles (Figure 3C-D) and development of chlamydospores in roots. (Figure 3E-F). Based on roots assessment we reported pattern of mycorrhizal colonization is of vesicular-arbuscular-hyphal $(V A H)$ type. Hence, present work endow with confirmation that, $C$. rollae is a mycorrhizal in status, which makes a new report of mycorrhizal endemic and endangered plant under genus Ceropegia from India.

\section{AMF Species Identification}

Total nine species of AMF under four families of Glomeromycetes such as: Acaulosporaceae Ambisporaceae, Gigasporaceae and Glomeraceae were identified in the rhizosphere soil of $C$. rollae scattered over 6 genera viz., Acaulospora, Ambispora, Dentiscutata, Entrophospora, Gigaspora and Glomus. Amongst the six genera, more number of species was occupied by Acaulospora (Table 2). The AMF species identified are viz., Acaulospora bireticulata Rothwell \& Trappe, A. laevis Gerd \&Trappe and A. undulata Sieverding; Ambispora leptoticha (N.C. Schenck \& G.S. Sm.) C. Walker, Vestberg \& A. Schüssle; Dentiscutata reticulata (Koske, Miller \& Walker) Sieverding, de Souza \& Oehl; Entrophospora baltica Blaz., Madej \& Tadych; Gigaspora gigantea (T.H. Nicolson \& Gerd.) Gerd. \& Trappe; Glomus austral (Berk.) S.M. Berch; and Scutellospora dipurpusescrns Mortan and Koske. The spore density (S) of all nine AMF was determined and expressed as number of spores per $100 \mathrm{~g}$ of rhizosphere soil of $C$. rollae which is presented in Table 3 . Based on spore density and relative abundance, only one species was dominant $(S \geq 40$ spores $100 \mathrm{~g}^{-1}$ soil, RA > 6\%) i.e. Acaulospora undulata Sieverding. The morphological characteristics of all eight species of AMF are illustrated in Figure 3.Thus in present investigation more number of AMF species recovered from rhizosphere soil of $C$. rollae were belonging to Acaulosporaceae (44.44\%) followed by Gigasporaceae (33.33\%). 
Review of literature at global context showed that AMF research work is mainly focused on Agriculture crops followed by medicinal and forest plants. However, rare endangered and threatened plants have not been investigated on large scale for their natural symbiotic partners to utilize the efficacy of these valuable AMF in plant conservation or habitat restoration plans. In general survey of global research particularly at Austria (Fuchs and Haselwandter, 2004), China (Shen and Wang, 2011), Ethiopia (Wubet et al., 2006), Oregon state US (Barroetavena et al., 1998), Poland (Zubek et al., 2009),
Southeast Florida US (Fisher and Jayachandran, 2002) and southeastern Spain (Azcón-Aguilar et al., 2010; Palenzuela et al., 2010, 2013a, 2013b, 2015) etc. has proved applications of AMF consortia, in conservation programmes of rare, endemic and endangered taxa. However, such study has been poorly documented from India. The endangered Indian plant species viz. Leptadenia reticulata, Mitragyna parvifolia, Withania coagulans (Panwar and Tarafdar, 2006) and Moringa concanensis (Panwar and Vyas, 2002) were only assessed for mycorrhizal status.

Table.1 Physicochemical properties of soil for endemic and endangered plant $C$. rollae

\begin{tabular}{cll}
\hline Sr. No. & \multicolumn{1}{c}{ Parameters } & \multicolumn{1}{c}{ Status } \\
\hline 1. & Colour & Slightly red \\
2. & Soil texture & Lateritic gravel \\
3. & Ph & $6.1 \pm 0.02$ \\
4. & Organic Carbon & $0.54 \%$ \\
5. & Organic Matter & $0.93 \%$ \\
6. & Carbonate & $12.09 \pm 0.01 \mathrm{mg} \cdot \mathrm{kg}^{-1}$ \\
7. & Phosphorus & $19.40 \pm 0.02 \mathrm{mg} \cdot \mathrm{kg}^{-1}$ \\
\hline
\end{tabular}

Table.2 Status of AMF colonization in roots of endemic and endangered plant $C$. rollae

\begin{tabular}{|c|c|c|c|}
\hline Particulars & \multicolumn{3}{|c|}{ AMF colonization in plant roots } \\
\hline Fungal structures & Vesicles & Arbuscules & Hyphae \\
\hline$M C p(\%)$ & $96.80 \pm 1.4$ & $27.70 \pm 0.5$ & $94.60 \pm 1.2$ \\
\hline$O I$ & Excellent ${ }^{e}$ & Moderate $^{m}$ & Excellent $^{e}$ \\
\hline$O C p(\%)$ & \multicolumn{3}{|c|}{$73.03 \pm 1.03$} \\
\hline OCI & \multicolumn{3}{|c|}{ Good $^{g}$} \\
\hline Smc Features & \multicolumn{3}{|c|}{$\begin{array}{l}\text { Formation thin walled vesicle/s (tnV) and thick walled } \\
\text { vesicles }(t k V)\end{array}$} \\
\hline Pmc & \multicolumn{3}{|c|}{$V A H$} \\
\hline Other fungal endophytes & \multicolumn{3}{|c|}{ Aabsent } \\
\hline
\end{tabular}

( \pm ) Standard error of mean; $(\boldsymbol{M C p})$ mean colonization percentage; (OI) Occurrence intensity [(p) 1-25\%, (m) 25$50 \%$, (e) >75\%], (Smc) Structures of Mycorrhizal colonization; (OCI) Overall colonization intensity[range of values is same as $\boldsymbol{O I}] ;(\boldsymbol{O C} \boldsymbol{p})$ Overall colonization percentage; (Pmc) Pattern of Mycorrhizal colonization; $(\operatorname{tnV})$ thin walled moniliform vesicle/s; $(t k V)$ thick walled vesicles; (VAH) vesicular-arbuscular-hyphal type. 
Fig.1 Study area for endemic and endangered plant Ceropegia rollae Hemadri: Naneghat hill top (site for natural population of plant species is encircled and arrow indicating popular site of mountaineers for rappelling); B\&C) Rappelling-anthropological activities during rainy season and D) DGA (3rd author) collecting samples

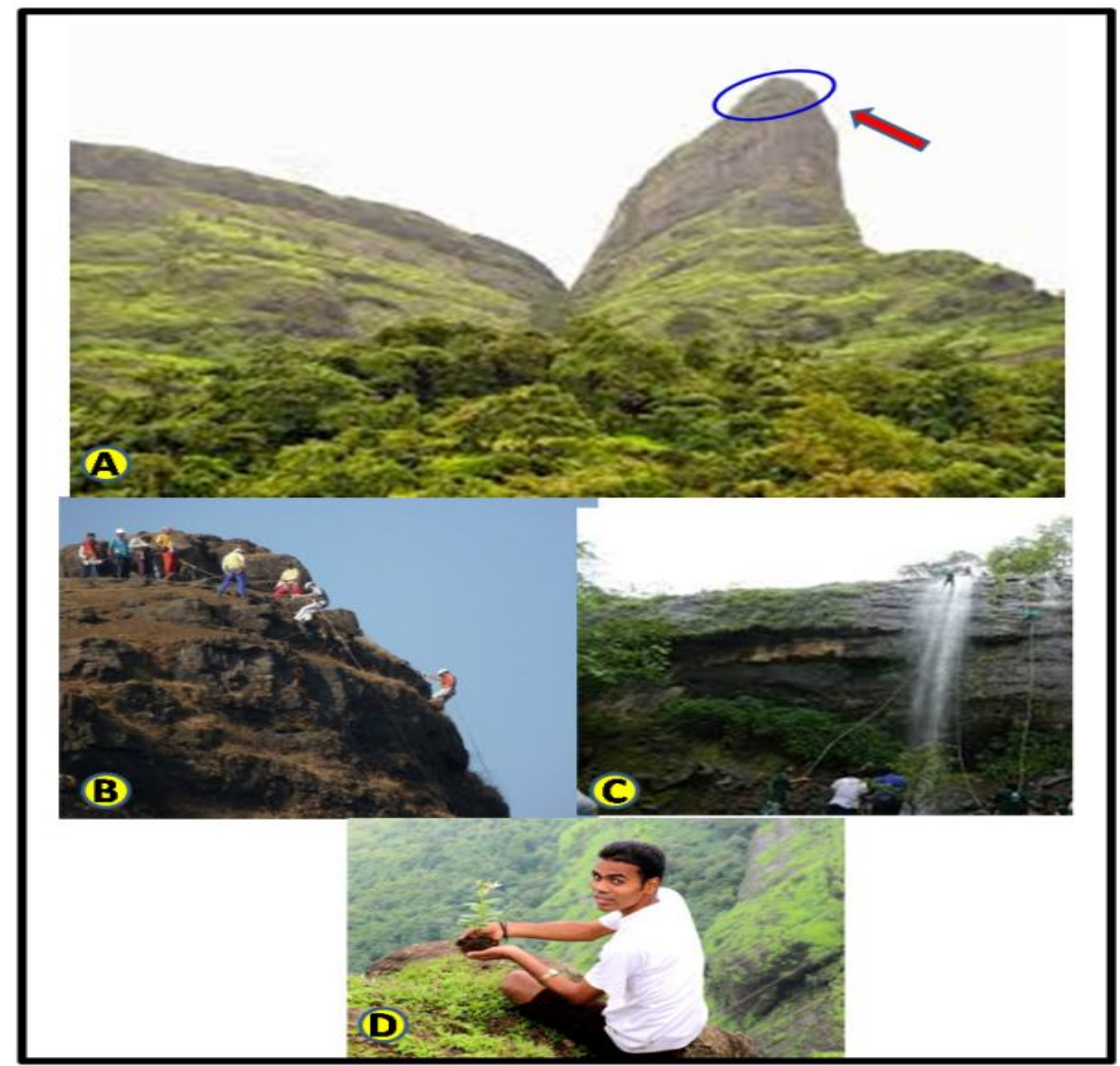


Fig.2 Endemic and endangered plant Ceropegia rollae Hemadri:

A) Habitat; B) Flower and C) Inflorescence.

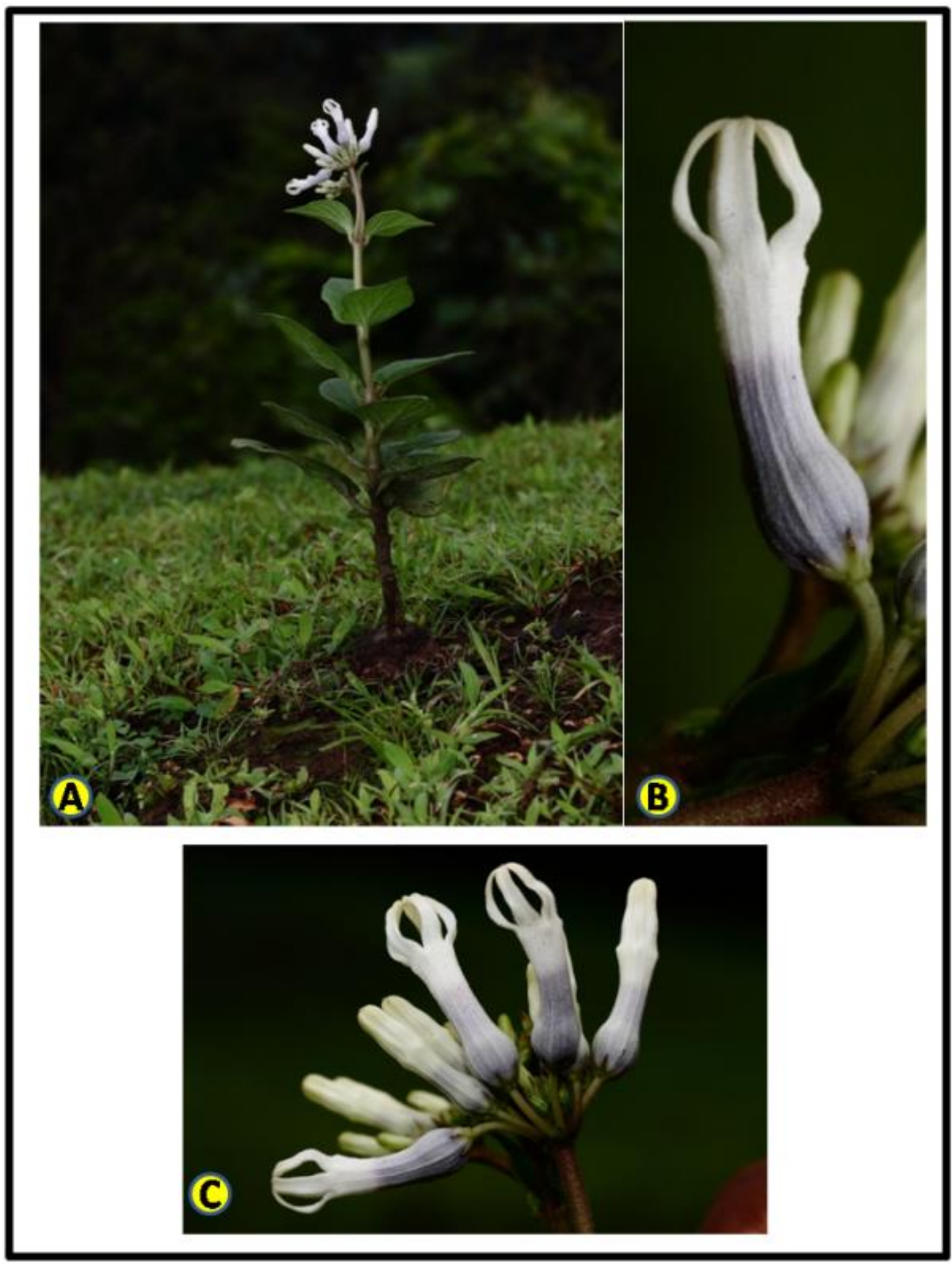


Fig.3 AMF colonization in roots of endemic and endangered plant Ceropegia rollae Hemadri:

A) Vesicular colonization (V); B) Arbuscular colonization (A); C) Thin walled vesicles $(\mathrm{tnV})$; D) Thick walled vesicles (tkV); E-\& F). Formation of chlamydospore (ch) on intra-radical hyphae (h).

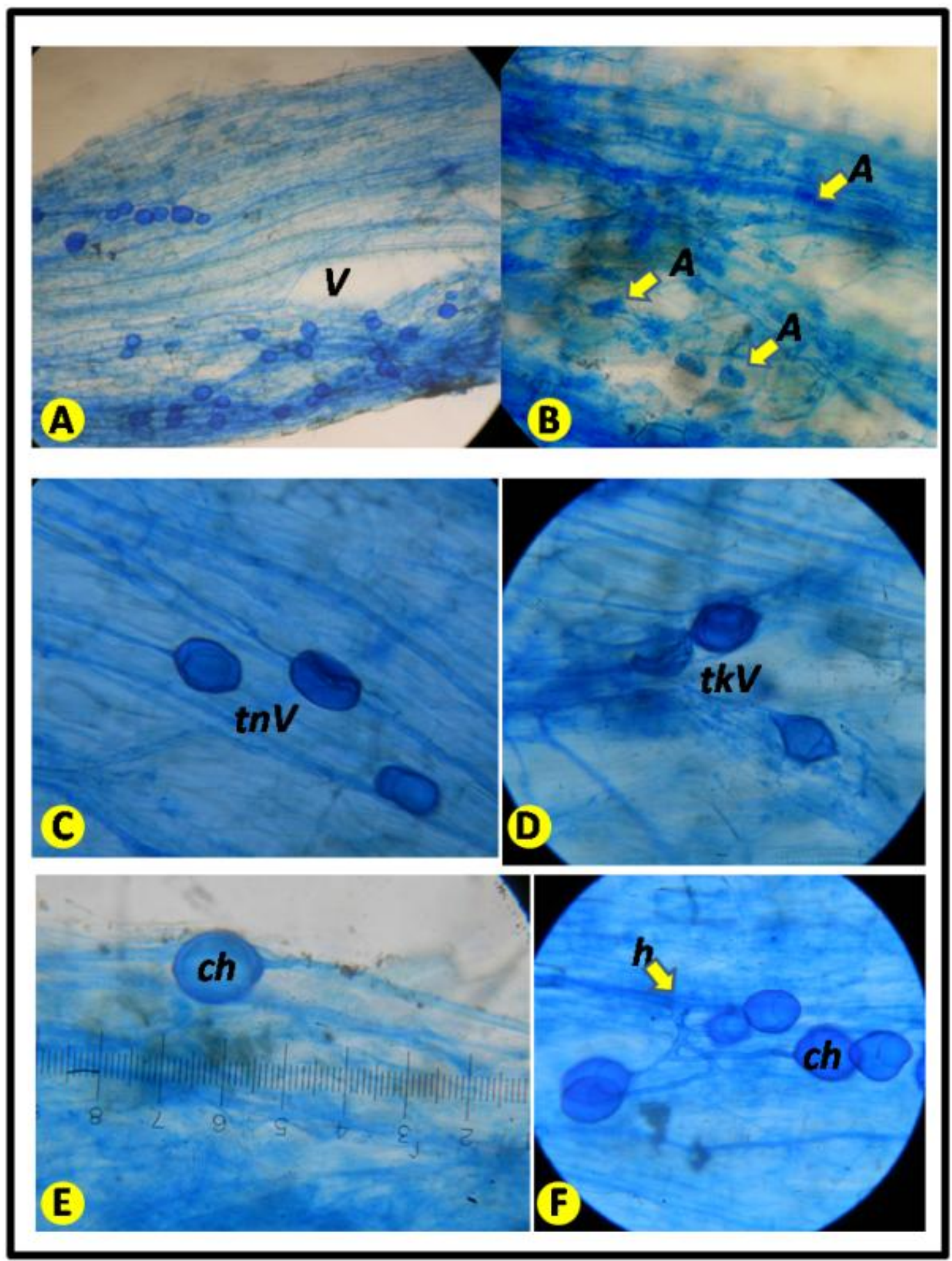


Fig.4 Morphological characteristics AMF spores in rhizosphere soil of endemic and endangered plant Ceropegia rollae Hemadri:

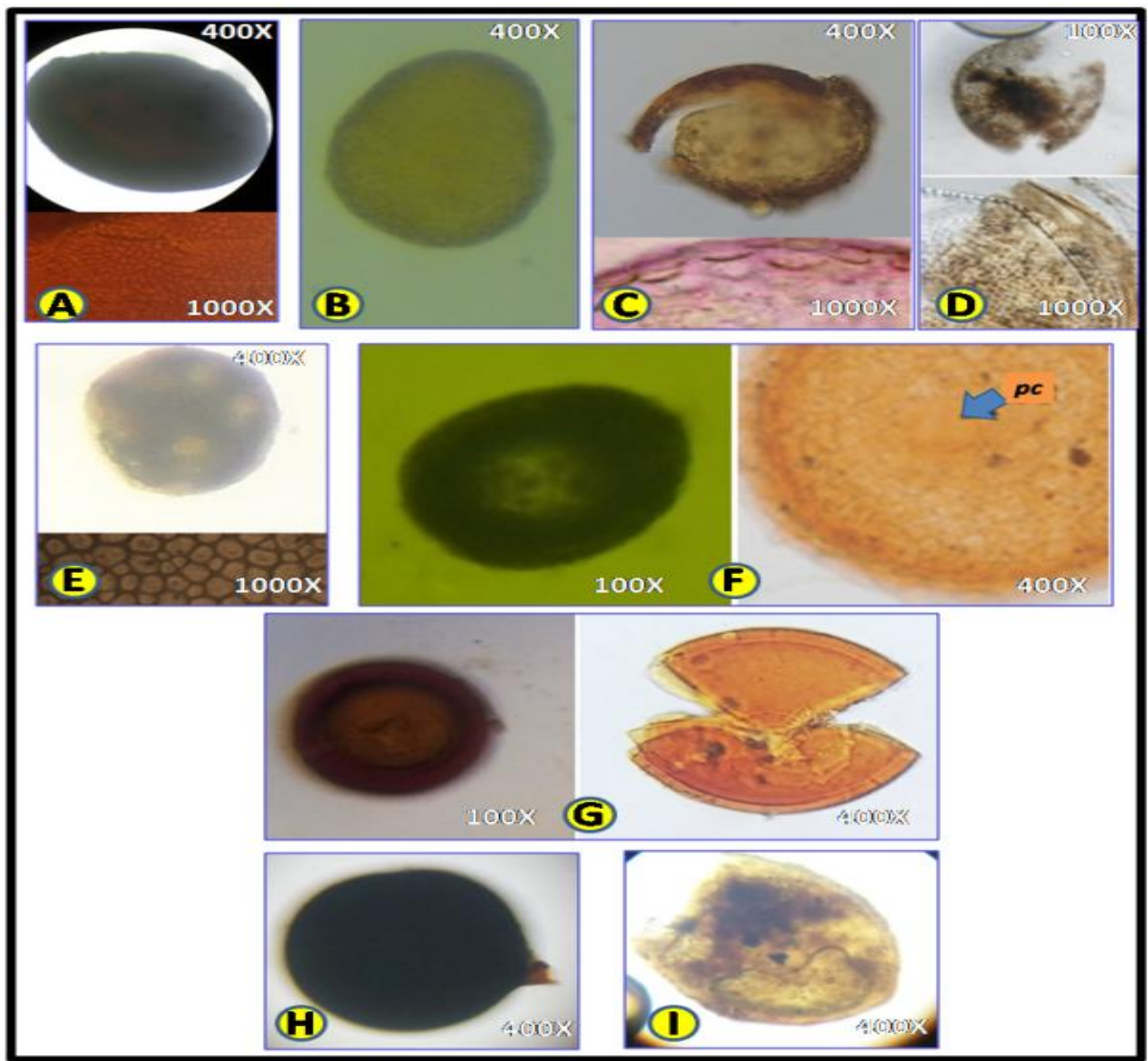

A) Acaulospora bireticulata Rothwell \& Trappe (Entire spore \& magnified view of middle lamella differentiating polygonal reticulum with ridges in depressed central stratum); B) Acaulospora laevis Gerd \&Trappe; C) Acaulospora undulata Sieverding (Spore with broken wall mounted in PVLG \& magnified view of undulate and roughened spore wall mounted in PVLG + Melzer's reagent); D) Ambispora leptoticha (N.C. Schenck \& G.S. Sm.) C. Walker, Vestberg \& A. Schüssle (Broken spore \& magnified view of crushed spore showing Acaulosporoid form of wall layers in PVLG mounts); E) Dentiscutata reticulata (Koske, Miller \& Walker) Sieverding, de Souza \& Oehl (Entire spore \& the outer wall layer ornamented with a reticulate pattern of polygonal shapes possessing densely packed spines at center); F) Entrophospora baltica Blaz., Madej \& Tadych (Entire spore mount in PVLG \& magnified view of spore showing cicatrix $(p c)$ formed due to detachment of saccule); G) Gigaspora gigantea (T.H. Nicolson \& Gerd.) Gerd. \& Trappe; H) Glomus austral (Berk.) S.M. Berch and I) Scutellospora dipurpusescrns Mortan and Koske. 
Table.3 Identified AMF with their spore density $(\mathrm{S})$ and relative abundance (RA) in rhizosphere of endemic and endangered plant $C$. rollae.

\begin{tabular}{|c|c|c|c|}
\hline Code & AMF Species & $\mathbf{S}$ & $\mathbf{R A}$ \\
\hline \multicolumn{4}{|c|}{ Acaulosporaceae } \\
\hline$B C A: M H_{R R S} 25$ & Acaulospora bireticulata Rothwell \& Trappe & 8 & 9.52 \\
\hline$B C A: M H_{R R S} 01$ & Acaulospora laevis Gerd \&Trappe & 4 & 4.76 \\
\hline$B C A: M H_{R R S} 35$ & Acaulospora undulata Sieverding & 41 & 48.81 \\
\hline$B C A: M H_{R R S} 33$ & Entrophospora baltica Blaz., Madej \& Tadych & 6 & 7.14 \\
\hline \multicolumn{4}{|c|}{ Ambisporaceae } \\
\hline$B C A: M H_{R R S} 13$ & $\begin{array}{l}\text { Ambispora leptoticha (N.C. Schenck \& G.S. Sm.) } \\
\text { C. Walker, Vestberg \& A. Schüssle }\end{array}$ & 3 & 3.57 \\
\hline \multicolumn{4}{|c|}{ Gigasporaceae } \\
\hline$B C A: M H_{R R S} 30$ & $\begin{array}{l}\text { Dentiscutata reticulata (Koske, Miller \& Walker) } \\
\text { Sieverding, de Souza \& Oehl }\end{array}$ & 2 & 2.38 \\
\hline$B C A: M H_{R R S} 18$ & $\begin{array}{l}\text { Gigaspora gigantea (T.H. Nicolson \& Gerd.) Gerd. } \\
\text { \& Trappe }\end{array}$ & 5 & 5.96 \\
\hline$B C A: M H_{R R S} 29$ & Scutellospora dipurpusescrns Mortan and Koske. & 9 & 10.72 \\
\hline \multicolumn{4}{|c|}{ Glomeraceae } \\
\hline$B C A: M H_{R R S} 20$ & Glomus austral (Berk.) S.M. Berch & 6 & 7.14 \\
\hline Total: AMF $9 \mathrm{~s}$ & pecies & 84 & 100 \\
\hline
\end{tabular}

According to Murthy et al., 2012 most of the endemic species of Western Ghats are restricted to a narrow range of distribution and some of them occur only in their type localities. Species like C. evansii, $C$. fantastica, C. huberi, C. lawii, C. maccannii, C. mahabalei, C. noorjahaniae, C. odorata, C. panchaganiensis, $C$. rollae, $C$. sahyadrica, and $C$. santapaui may become extinct in few decades unless conservation measures are taken.

The current state of knowledge about AMF occurrence in threat prone sites is poorly known to Indian RET plant species. So to offer a strategic perspective to increase awareness about the importance of conserving these useful microbial symbionts of $C$. rollae our findings could be stand praiseworthy. At present, along with conventional and modern methods of plant conservation AMF potential is equally needed to utilize.

Thus, we recognized, to the best of our knowledge for the first time, the mycorrhizal status of an endemic and critically endangered plant $C$. rollae from India. The plant was studied for the first time with reference to root colonization and associated 
AMF species in rhizosphere of it and confirmed the mycorrhizal nature of plant. Such inventory would provide prerequisite knowledge for tapping the absolute potential of mycorrhizal fungi in habitat restoration and conservation of $C$. rollae in near future. Nevertheless, it needs further extension of work to produce native isolates of these fungal species in pure form through aexenic cultures so that efficacy of mycorrhizal isolates either as consortia or alone would be checked through experiments.

\section{References}

Azcón-Aguilar, C., Palenzuela, J., RuízGirela, M., Ferrol, N., Azcón, R., Irurita, J.M., Barea, J.M. 2010. Análisis de la diversidad de micorrizas y hongos micorrícicos asociados a especies de la flora amenazada del Paque Nacional de Sierra Nevada. 2006-2009. Naturaleza y Parques Nacionales Serie Investigación en la Red. In: Ramírez, L., Asencio, B. (Eds.), Proyectos de Investigación en Parque Nacionales. Organismo Autónomo Parques Nacionales, Madrid, pp. 173e190.

Barroetavena, C., Gisler, S.D., Luoma, D.L., Meinke, R.J. 1998. Mycorrhizal status of the endangered species Astragalus applegatei Peck as determined from a soil bioassay. Mycorrhiza, 8: $117-$ 119.

Bothe, H., Turnau, K., Regvar, M. 2010. The potential role of arbuscular mycorrhizal fungi in protecting endangered plants and habitats Mycorrhiza, 20(7): 445-57.

Brundrett, M., Bougher, N., Dell, B., Grove, T., Malajczuk, N. 1996. Working with Mycorrhizas in Forestry and Agriculture. ACIAR Monograph 32, Pirie Printers, Canberra, Australia, pp 374.
BSI. 2002. Studies on Rare and Endangered Species http://www.envfor.nic.in /bsi/research.html.

CITES. 2007. Proposals resulting from reviews by the Plants CommitteesProp.11.01.

Dandan, Z., Zhiwei, Z. 2007. Biodiversity of arbuscular mycorrhizal fungi in the hotdry valley of the Jinsha River, southwest China. Appl. Soil Ecol., 37: 118-128.

Diwakar, P.G., Singh, R.Kr. 2011. A new variety of Ceropegia attenuata Hook. (Asclepiadaceae) from Mookambika Wildlife Sanctuary, Karnataka, India. Indian J. Forestry, 34: 209-212.

Fisher, J.B., Jayachandran, K. 2002. Arbuscular Mycorrhizal Fungi Enhance Seedling Growth in Two Endangered Plant Species from South Florida. Int. J. Plant Sci., 163(4): 559566.

Fisher, J.B., Jayachandran, K. 2002. Arbuscular Mycorrhizal Fungi Enhance Seedling Growth in Two Endangered Plant Species from South Florida. Int. J. Plant Sci., 163(4): 559566.

Fuchs, B., Haselwandter, K. 2004. Red list plants: colonization by arbuscular mycorrhizal fungi and dark septate endophytes, Mycorrhiza, 14(4): 277281.

Fuchs, B., Haselwandter, K. 2004. Red list plants: colonization by arbuscular mycorrhizal fungi and dark septate endophytes, Mycorrhiza, 14(4): 277281.

Gadgil, M. 2004. ENVIS Technical Report No. 16, Environmental Information, Bangalore, http://www.ces.iisc.ernet.in/hpg/envis pp. 96-98.

Gaur, A., Adholeya, A. 1994. Estimation of VAMF spores in soil: a modified method, Mycorrhiza News, 6: 10-11. 
Gerdemann, J.W., Nicolson, T.H. 1963. Spores of mycorrhizal Endogone species extracted from soil by wet sieving and decanting. Trans. Br. Mycol. Soc., 46: 235-244.

Goyal, D., Bhadauria, S. 2006. In vitro propagation of Ceropegia bulbosa using nodal segments. Indian $J$. Biotechnol., 5: 565-567.

Holl, K.D., Hayes, G.F. 2006. Challenges to Introducing and Managing Disturbance Regimes for Holocarpha macradenia, an Endangered Annual Grassland Forb, Conservation Biol., 20(4): 1121-1131.

Jackson, M.L. 1967. Soil chemical analysis, Prentice Hall of Indian Private Limited, New Delhi. pp.1-498.

Jagtap, A.P., Das-Das, S.K. 2001, Asclepiadaceae, In: Singh, N.P., Lakshminarsimhan, P., karthikeyan, S. and Prasanna P.V., Flora of Maharashtra state: Dicotyledones Vol 2, Botanical survey of India, Calcutta, 334-389.

Kambale, S.S., Chandore, A.N., Yadav, S.R. 2012. Ceropegia concanensis, a new species (Apocynaceae: Ceropegieae) from Western Ghats, India. Kew Bull., 67: 1-6.

Kamble, V.R., Kanoujiya, L.R., Agre, D.G. 2012. VAM colonization and inoculum production for Ophioglossum conservation. Acta Biologica Indica, 1(2): 220-224.

Malpure, N.V., Kamble, M.Y., Yadav, S.R. 2006. A new species of Ceropegia L. (Asclepiadaceae) from the Western Ghats of India with a note on series Attenuatae Huber. Curr. Sci., 91: 1140-1142.

Morton, J.B. 1988. Taxonomy of mycorrhizal fungi: classification, nomenclature, and identification. Mycotaxon., 32: 267 -324.
Murthy, K.S.R., Kondamudi, R., Reddy, M.C., Karuppusamy, S., Pullaiah, T. 2012. Check-list and conservation strategies of the genus Ceropegia in India. Int. J. Biodiversity and Conservation, Vol. 4(8): 304-315.

Nayar, M.P., Sastry, A.R.K. 1987. Red Data Book of Indian plants, Vol. 1. Botanical Survey of India, Calcutta, pp. 49-71.

Olsen, S.R., Cole, C.V., Watanabe, F.S., Dean, L.A. 1954. Estimation of available phosphorus in soils by extraction with sodium bicarbonate. USDA Circ. No. 939. U.S. Dept. Agric. Washington, D.C.

Palenzuela, J., Azcón-Aguilar, C., Barea, J., Silva, G.A., Oehl, F. 2013a. Acaulospora pustulata and Acaulospora tortuosa, two new species in the Glomeromycota from Sierra Nevada National Park (southern Spain) Nova Hedwigia Vol. 97(3-4): 305-319.

Palenzuela, J., Azcón-Aguilar, C., Barea, J., Silva, G.A., Oehl, F. 2013b. Septoglomus altomontanum, a new arbuscular mycorrhizal fungus from mountainous and alpine areas in Andalucía (southern Spain). IMA Fungus, 4(2): 243-249.

Palenzuela, J., Azcón-Aguilar, C., Barea, J., Silva, G.A.D., Oehl, F. 2015. Acaulospora baetica, a new arbuscular mycorrhizal fungal species from two mountain ranges in Andalucía (Spain). Nova Hedwigia Vol. 101 (2015) Issue 3-4, 463-474.

Palenzuela, J., Barea, J.M., Ferrol, N., Azcón-Aguilar, C., Oehl, F. 2010. Entrophospora nevadensis, a new arbuscular mycorrhizal fungus from Sierra Nevada National Park (southeastern Spain). Mycologia, 102: $624 \mathrm{e} 632$. 
Panwar, J., Tarafdar, J.C. 2006. Distribution of three endangered medicinal plant species and their colonization with arbuscular mycorrhizal fungi," J. Arid Environ., 65(3): 337-350.

Panwar, J., Vyas, A. 2002. AM fungi: A biological approach towards conservation of endangered plants in Thar desert, India. Curr. Sci., 82: 576578.

Phillips, J.M., Hayman, D.S. 1970. Improved procedure for clearing roots and staining parasitic and vesicular arbuscular mycorrhizal fungi for rapid assessment of infection, Trans. Br. Mycol. Soc., 55: 158-161.

Piper, C.S. 1966. Soil and Plant Analysis, (Hans Publishers, Bombay. pp 368.

Schenk, N.C., Perez, Y. 1990. Manual for the identification of VA - Mycorrhizal fungi, third edition. University of Florida, Gainesville, Florida, pp. 249.

Shen, S.K., Wang, Y.H. 2011. Arbuscular mycorrhizal (AM) status and seedling growth response to indigenous AM colonisation of Euryodendron excelsum in China: implications for restoring an endemic and critically endangered tree. Australian $J$. Bot., 59(5): 460-467.

Singh, R.Kr. 2015. Ceropegia jainii and $C$. rollae (Apocynaceae) at the brink of extinction TAPROBANICA. 07(02): 87-90.

Smith, S.E., Read, D.J. 1997. Mycorrhizal symbiosis, second edition, Academic press, London. pp. 1-605.
Turnau, K., Haselwandter, K. 2002. Arbuscular mycorrhizal fungi, an essential component of soil microflora in ecosystem restoration. In: Gianinazzi, S., Schüepp, H., Barea, J. M. and Haselwandter, K. (Eds), Mycorrhizal technology in agriculture. From genes to mycorrhiza application, Birkhauser Verlag, Switzerland, pp. 137-149.

van Reeuwijk, L.P. 2002. Procedures for soil analysis: Technical paper-9; sixth edition, International Soil Reference And Information Centre Publishers, P.O. Box 353, 6700 AJ Wageningen, The Netherlands, pp. 1-120.

Walkley, A., Black, I.A. 1938. An examination of Degtjareff method for determining soil organic matter and a proposed modification of the chromic acid titration method. Soil Sci., 37: 2937.

Wubet, T., Weiss, M., Kottke, I., Oberwinkler, F. 2006. Two threatened coexisting indigenous conifer species in the dry Afromontane forests of Ethiopia are associated with distinct arbuscular mycorrhizal fungal communities. Canadian J. Bot., 84: 1617-1627.

Zubek, S., Turnau, K., Tsimilli-Michael, M., Strasser, R.J. 2009. Response of endangered plant species to inoculation with arbuscular mycorrhizal fungi and soil bacteria. Mycorrhiza, 19(2): 113-123.

\section{How to cite this article:}

Vishal R. Kamble, Ruchira R. Sutar and Dinesh G. Agre. 2016. A New Record of Endemic and Critically Endangered Mycorrhizal Plant: Ceropegia rollae Hemadri from India. Int.J.Curr.Microbiol.App.Sci. 5(6): 190-203. doi: http://dx.doi.org/10.20546/ijcmas.2016.506.023 